\title{
Amomum sahyadricum (Zingiberaceae), a New Species from the Western Ghats, India
}

\author{
V. P. Thomas, M. Sabu, * and K. M. Prabhu Kumar \\ Department of Botany, University of Calicut, P.O. Calicut University, 673 635, Kerala, India \\ *Corresponding author: msabu9@gmail.com
}

Abstract. The new species Amomum sahyadricum V. P. Thomas \& M. Sabu (Zingiberaceae) is described and illustrated from the Western Ghats, India. The new species is related to A. muricatum Bedd., but differs from it in the smaller habit $(33-60 \mathrm{~cm}$ vs. 70$150 \mathrm{~cm}$ in A. muricatum), the prominently raised veins on the adaxial surface of the leaf lamina (vs. immersed venation), the fleshy and thick bracts (vs. membranous bracts), 2-horned bracteoles, the calyx with three mucronate teeth, dorsal corolla lobe mucronate at apex, and the rugose to muricate fruits (vs. echinate fruits). IUCN status, distribution, phenology, and ecological details are provided.

Key words: Amomum, India, IUCN Red List, Western Ghats, Zingiberaceae.

Amomum Roxb. (Zingiberaceae) is the second largest genus in the ginger family after Alpinia Roxb. Amomum comprises ca. 150 to 180 species and is widely distributed in Southeast Asia (Xia et al., 2004). In India, Amomum is mainly distributed in the northeast, but also is found from peninsular India and the Andaman and Nicobar Islands. Sabu (2006) recorded six species of Amomum from South India. Thomas et al. (2009) reported the occurrence of $A$. fulviceps Thwaites from Western Ghats. Thomas et al. (2012) and Thomas and Sabu (2012) described an additional three species from Western Ghats, viz. $A$. nilgiricum V. P. Thomas \& M. Sabu, A. agastyamalayanum V. P. Thomas \& M. Sabu, and A. newmanii M. Sabu \& V. P. Thomas, which raises to 10 the number of species reported for peninsular India. During the collection of Zingiberaceae from Agastyamala in the Western Ghats, Kerala, India, we encountered an interesting specimen of Amomum, distinct from any known described species. On critical study, we determined this to be a new species, and it is herein described and illustrated.

Amomum sahyadricum V. P. Thomas \& M. Sabu, sp. nov. TYPE: India. Kerala: Thiruvananthapuram, Agastyamala, Athirumala, $8^{\circ} 37^{\prime} 3.8^{\prime \prime} \mathrm{N}$, $77^{\circ} 13^{\prime} 47^{\prime \prime} \mathrm{E}, 1014 \mathrm{~m}, 1$ Mar. 2008, V. P. Thomas \& A. V. Prasanth 103034 (holotype, CALI; isotype, MH). Figure 1.
Amomo muricato Bedd. similis, habitu minore, foliis adaxialiter venis prominente elevatis, bracteis carneis crassis, bracteolis bicornutis, calyce cum tres dentis mucronatis, corollae lobo dorsali mucronatis, fructibus rugosisve muricatis differt.

Rhizome slender, stoloniferous, creeping, 3-7 mm thick, length:breadth ratio ca. 30:1, sheathed with scales; scales chartaceous, 2-2.5 cm, margin distantly ciliate, apex rounded, a cusp (ca. $1 \mathrm{~mm}$ ) just behind the apex, puberulous externally; leafy shoots $33-60 \mathrm{~cm}$, leafless shoots $18-30 \mathrm{~cm}$ long. Leaf sheaths 1.1-1.4 cm wide at base, green, margin sparsely ciliate, apex slightly emarginate with a cusp just behind apex, puberulous externally; leaves 6 or 7 per leafy shoot; laminae elliptic to elliptic-lanceolate, $12-26 \times 2.9-5 \mathrm{~cm}$, base cuneate, margin slightly wavy, apex acuminate, glabrous on both surfaces; venation prominently raised adaxially; petiole 4-7 $\mathrm{mm}$, green, glabrous; ligule entire, 3-5 mm, coriaceous, glabrous with margin ciliate, apex rounded. Inflorescence radical, arising from the rhizome, 12-19 cm, 1 or 2 open at a time; peduncle 9-13 cm; bracts ovate to oblong, 2.5-3.5 × 1.5-1.7 $\mathrm{cm}$, thick and fleshy, pink-red, margin ciliate, apex acute, pubescent externally, glabrous internally; bracteole tubular, 2-lobed, 1.9-2.2 cm × 5-6 mm, 2-horned, these resembling deer horns, membranous, pale pink, pubescent outside, glabrous inside. Flowers 4.2-5 cm, yellow; calyx tubular, 2.4-2.6 $\mathrm{cm} \times 5-6 \mathrm{~mm}$, pale pink, apex with 3 mucronate teeth, slightly curved and flattened, mucro 4-6 mm, margin glabrous, pubescent outside, glabrous within; corolla tube $1.5-2.1 \mathrm{~cm}, 4-5 \mathrm{~mm}$ wide at mouth, pale yellow, densely pubescent externally, glabrous internally except near mouth; dorsal corolla lobe ovate, yellow, 1.9-2.2 × 1.2-1.5 cm, margin glabrous, apex with ca. $2 \mathrm{~mm}$ mucro, puberulous toward base externally, glabrous within; lateral corolla lobes oblong, 1.9-2 cm $\times 5-6 \mathrm{~mm}$, rarely margin ciliate, apex nearly rounded, one side slightly folded, pubescent toward base externally, glabrous within; labellum obovate, 2.7-3.1 × 1.3-2.2 cm, 3-lobed, median lobe bifid, yellow, dark reddish maroon stripes at center, margin slightly wavy, pubescent 

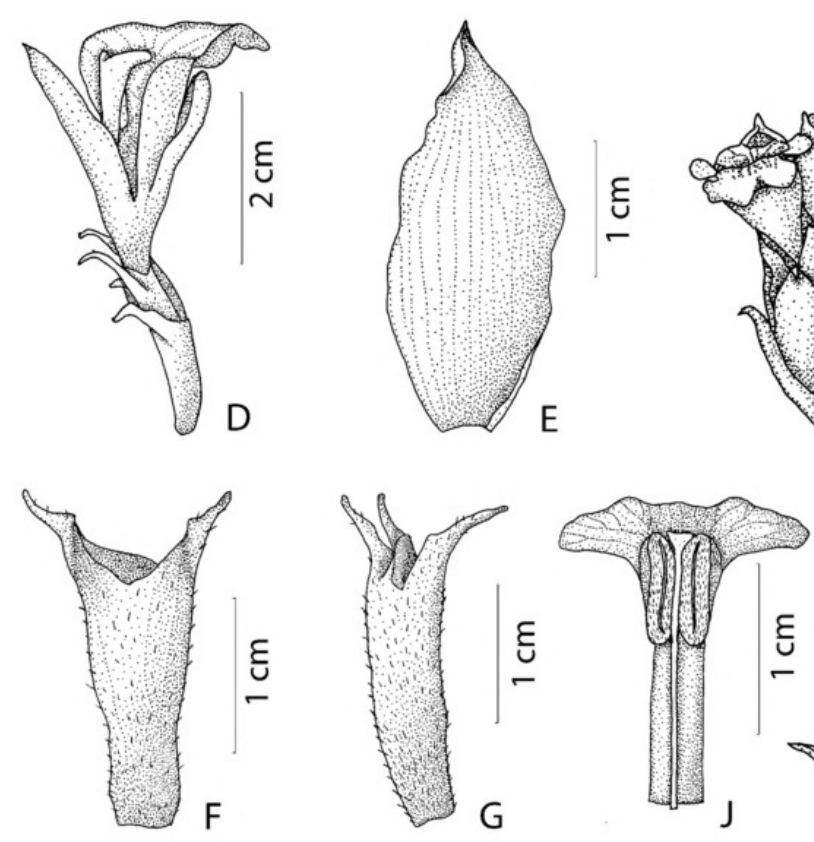

G
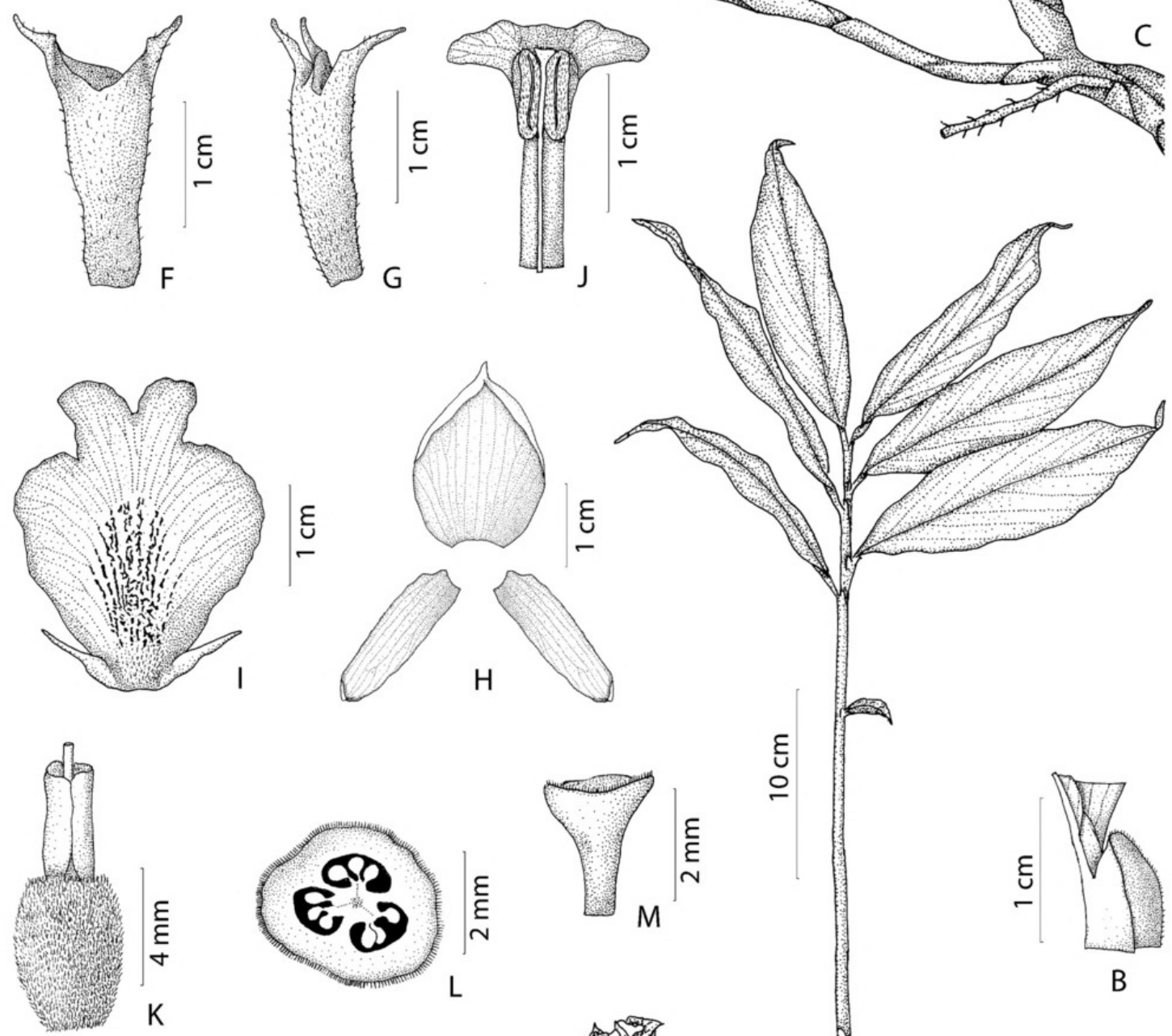

1
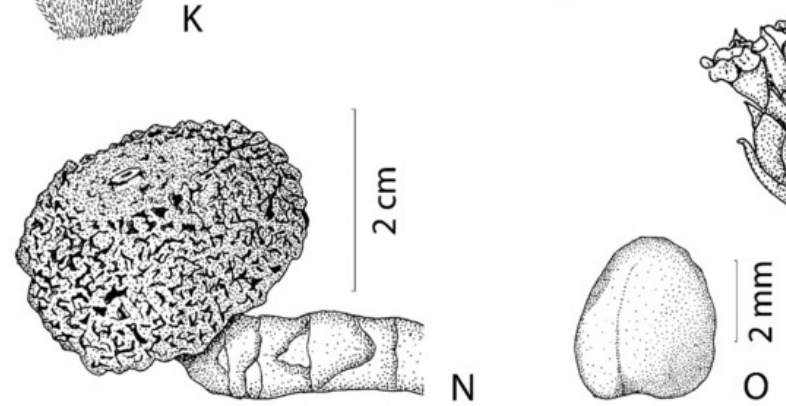

B

Figure 1. Amomum sahyadricum V. P. Thomas \& M. Sabu. —A. Habit. —B. Ligule. —C. Inflorescence. -D. Flower. -E. Bract. -F. Bracteole. - G. Calyx. - H. Corolla lobes. - I. Labellum with lateral staminodia. -J. Stamen. -K. Ovary with epigynous glands and style. - L. Cross section of ovary. - M. Stigma. - N. Fruit. - O. Seed (aril removed). A-M drawn from the holotype V. P. Thomas \& A. V. Prasanth 103034 (CALI); N, O drawn from V. P. Thomas \& K. M. Prabhu Kumar 115581 (CALI). 
inside near throat; lateral staminodia acute, flattened, 5-7 mm, thin, yellow, pubescent toward base, glabrous toward apex; stamen 1.7-1.9 $\mathrm{cm}$, shorter than labellum, filament pale yellow, $8-10 \times 2.5-3$ $\mathrm{mm}$, glabrous on both sides, connective glabrous, produced into crest; crest yellow, deep yellow on lateral sides, 1.4-1.5 $\mathrm{cm} \times 3-4 \mathrm{~mm}$, semi-lunar with truncate apex, glabrous; anther thecae oblong, 6-7 $\mathrm{mm}$, creamy white, base nearly rounded, apex rounded, pubescent; dehiscence linear, complete; ovary ca. $5 \times 3-4 \mathrm{~mm}$, densely pubescent; locules 3 , pubescent outside; ovules on axile placentae; style 3$3.6 \mathrm{~cm}$, sparsely pubescent, glabrous proximally; stigma cup-shaped, ca. $1 \mathrm{~mm}$ across, ostiole apical, ciliate; epigynous glands 2, oblong, 3-4 mm, cream colored, apex slightly lobed, glabrous. Capsules 1 to 3 per spike, globose, $1.5-3 \times 1.5-3 \mathrm{~cm}$, rarely slightly 3 -lobed, maroon, rarely tinged with green, rugose to muricate, pubescent externally; seeds ovate, $3-4 \times 3 \mathrm{~mm}$, brown, aromatic, arillate, glabrous; aril white.

Distribution and habitat. Amomum sahyadricum grows under evergreen forest in the Agasthyamalai Hills, Meenmutty-Kulamavu (Idukki District, Kerala) and Valparai (Coimbatore District, Tamil Nadu) of the Western Ghats, in Kerala, India, at an altitude of ca. 1000 m.s.m.

IUCN Red List category. Apart from the type locality, we were able to collect specimens of this species from two other localities in the Western Ghats. To this point, at all known sites we have located only a few populations and these may be considered to be in locations that are prone to destruction in the near future because of various human activities. According to our current knowledge of the species and using the IUCN Red List categories and criteria (IUCN, 2001, 2010), Amomum sahyadricum is tentatively classified as Endangered or EN Blab(ii, iii).

Etymology. The epithet of the new species, sahyadricum, is derived from the Malayalam name of the type locality in the Western Ghats of India.

Phenology. Plants of Amomum sahyadricum were observed with flowers from February to March and with mature fruits in July.

Relationships. Amomum sahyadricum is similar to A. muricatum of South India in having large yellow flowers $(4.2-5 \mathrm{~cm})$, slender, creeping, stoloniferous rhizome and tri-lobed labellum with bifid mid-lobe. The former can be distinguished from the latter by having a smaller habit (33-60 $\mathrm{cm})$, prominently raised veins on the adaxial surface of the lamina, thick and fleshy bracts, 2-horned (resembling a pair of deer antlers) bracteoles, calyx with 3 mucronate teeth, dorsal corolla lobe with mucronate apex and fruit rugose to muricate (Fig. 1). In contrast, $A$. muricatum is taller $(70-150 \mathrm{~cm})$ and has venation that is immersed on the leaf lamina, membranous bracts, a bracteole that lacks a horned pair, a calyx that lacks mucronate teeth, a dorsal corolla lobe with rounded apex, and echinate fruit.

\section{Key to the Species of Amomum in South India}

1a. Rhizome stoloniferous, rhizome length:breadth* ratio more than 10:1; habit as diffuse .......... 2

1b. Rhizome non-stoloniferous, rhizome length: breadth ratio less than $7: 1$; habit as distinct clumps .............................. 6

2a. Leaves silvery, silky beneath, with appressed pubescence; labellum unlobed; fruit slightly ribbed ................. A. hypoleucum Thwaites

2b. Leaves pale green beneath, glabrous; labellum 3lobed; fruit not ribbed $\ldots \ldots \ldots \ldots \ldots \ldots \ldots \ldots \ldots$

3a. Ligule 25-45 mm long, membranous ......... ..................... A. masticatorium Thwaites

3b. Ligule $2-7 \mathrm{~mm}$ long, coriaceous ............ 4

4a. Flowers 1.8-2 cm long; labellum 1.3-1.6 cm long .................... Agastyamalayanum

4b. Flowers $4.2-5.3 \mathrm{~cm}$ long, labellum $2.5-3.3 \mathrm{~cm}$

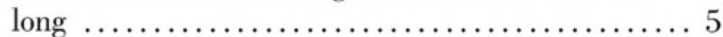

5a. Bracts fleshy; bracteoles 2-lobed, 2-horned; dorsal corolla lobe with mucronate apex; fruit rugose to muricate ................ A. sahyadricum

5b. Bracts membranous; bracteoles 2- or 3-lobed, horns absent; dorsal corolla lobe without an apical mucro; fruit echinate ......... A. muricatum

6a. Ligule bifid $\ldots \ldots \ldots \ldots \ldots \ldots \ldots \ldots \ldots \ldots \ldots \ldots \ldots \ldots \ldots$

6b. Ligule entire, not bifid ................... 8

7a. Leaves tomentose beneath; fruit winged ....... A. pterocarpum Thwaites

7b. Leaves glabrous beneath; fruit not winged..... .......... A. cannicarpum (Wight) Benth. ex Baker

8a. Labellum not lobed, rhomboid; ligule $4.5-9 \mathrm{~cm}$ long $\ldots \ldots \ldots \ldots \ldots \ldots \ldots \ldots \ldots \ldots \ldots \ldots \ldots \ldots \ldots$. nilgiricum

8b. Labellum 3-lobed, obovate; ligule $0.5-3.8 \mathrm{~cm}$

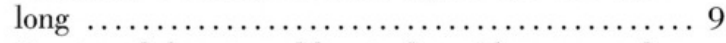

9a. Bracts red; bracts and bracteoles with appressed fulvous hairs; labellum uniformly cream colored; anther crest emarginate ............. A. fulviceps

9b. Bracts maroon; bracts or bracteoles pubescent or puberulous; labellum with maroon design on yellow ground; anther crest fan-shaped ........ 10

10a. Leaves glabrous beneath; flowers $5-5.5 \mathrm{~cm}$ long; capsule green at maturity ........... A. newmanii

10b. Leaves pubescent beneath; flowers $2.5-3.4 \mathrm{~cm}$ long; capsule maroon at maturity $\ldots \ldots \ldots \ldots$. .................... Ahaticum K. G. Bhat

* Rhizome length:breadth ratio is length (including nodes and internodes) of rhizome between two adjacent aerial shoots relative to the average diameter or thickness of the rhizome. 
Paratypes. INDIA. Kerala: Thiruvananthapuram, Agastyamala, Athirumala, 5 July 2009, V. P. Thomas \& K. M. Prabhu Kumar 115581 (CALI), 27 Feb. 2008, V. P. Thomas \& A. V. Prasanth 103023 (CALI), 2 Mar. 2008, V. P. Thomas \& A. V. Prasanth 103038 (MO), 7 Feb. 2006, E. Sanoj 86183 (CALI); Nadukanippara, 7 Feb. 2006, E. Sanoj 86186 (CALI); Idukki Distr., Meenmutty-Kulamavu, 24 Feb. 1984, A. G. Pandurangan 78077 (MH). Tamil Nadu: way to Valparai, 31 Jan. 2006, M. Sabu \& E. Sanoj 86177 (CALI).

Acknowledgments. The authors are grateful to the Department of Biotechnology and to the Department of Science and Technology, New Delhi, for financial assistance for research projects on Indian Zingiberaceae (BT/PR6735/PBD/16/605/2005, dated September 29, 2006, and SP/SO/PS-115/2009, dated May 10, 2010). We are thankful to Dr. Mark Newman, RBGE, for his critical comments on the taxonomic identity of the new species. Thanks are also due to Dr. J. F. Veldkamp, Leiden, The Netherlands, for the Latin diagnosis. We are grateful to the Forest Department, Government of Kerala, for the necessary forest permissions.

\section{Literature Cited}

IUCN. 2001. IUCN Red List Categories and Criteria, Version 3.1. Prepared by IUCN Species Survival Commission. IUCN, Gland, Switzerland, and Cambridge, United Kingdom.

IUCN. 2010. Guidelines for using the IUCN Red List Categories and Criteria, Version 8. Prepared by the Standards and Petitions Subcommittee, Gland, Switzerland.

Sabu, M. 2006. Zingiberaceae and Costaceae of South India. Indian Association for Angiosperm Taxonomy, Calicut University, Kerala.

Thomas, V. P. \& M. Sabu. 2012. Two new species of Amomum (Zingiberaceae) from Western Ghats, India. Edinburgh J. Bot. 69(2): 313-321.

Thomas, V. P., E. Sanoj, M. Sabu \& A. V. Prasanth. 2009. On the identity and occurrence of Amomum fulviceps (Zingiberaceae) in India. Rheedea 19(1 \& 2): 13-17.

Thomas, V. P., M. Sabu \& K. M. Prabhu Kumar. 2012. Amomum nilgiricum (Zingiberaceae) a new species from Western Ghats, India. PhytoKeys 8: 99-104.

Xia Y. M., W. J. Kress \& L. M. Prince. 2004. Phylogenetic analysis of Amomum (Alpinioideae: Zingiberaceae) using ITS and matK DNA sequence data. Syst. Bot. 29(2): 334344. 


\section{$2 \mathrm{BHL}$ Biodiversity Heritage Library}

Thomas, V. P., Sabu, M., and Kumar, K M Prabhu. 2013. "Amomum sahyadricum (Zingiberaceae), a New Species from the Western Ghats, India." Novon a journal of botanical nomenclature from the Missouri Botanical Garden 22(3), 321-324. https://doi.org/10.3417/2010090.

View This Item Online: https://www.biodiversitylibrary.org/item/196082

DOI: https://doi.org/10.3417/2010090

Permalink: https://www.biodiversitylibrary.org/partpdf/218576

\section{Holding Institution}

Missouri Botanical Garden, Peter H. Raven Library

\section{Sponsored by}

Missouri Botanical Garden

\section{Copyright \& Reuse}

Copyright Status: Permission to digitize granted by rights holder Rights: https://www.biodiversitylibrary.org/permissions

This document was created from content at the Biodiversity Heritage Library, the world's largest open access digital library for biodiversity literature and archives. Visit BHL at https://www.biodiversitylibrary.org. 